\title{
Kajian Pemasangan Pipa Air Bersih Melayang dalam Air Laut untuk Mendukung Perkembangan Pariwisata di Nusa Ceningan dan Lembongan
}

\author{
Made Suarda ${ }^{1)^{*}}$, I Gusti Komang Dwijana ${ }^{1)}$ \\ ${ }^{1)}$ Program Studi Teknik Mesin Fakultas Teknik Universitas Udayana, Kampus Bukit Jimbaran - Bali
}

Naskah diterima 07/10/2019; direvisi 01/04/2020; disetujui 15/04/2020

doi: https://doi.org/10.24843/JEM.2020.v13.i01.p03

\begin{abstract}
Abstrak
Air bersih merupakan kebutuhan dasar untuk kehidupan manusia. Demikian pula aktivitas kehidupan di pulau Nusa Ceningan dan Lembongan membutuhkan air bersih. Mengingat kedua pulau tersebut merupakan destinasi wisata pavorit dan berkembang pesat, maka disamping untuk kehidupan masyarakat sehari-harinya (7153 jiwa), ketersediaan air bersih sangat dibutuhkan untuk hotel dan aktivitas pendukung pariwisata. Namun, di kedua pulau tersebut tidak tersedia sumber air bersih. Oleh sebab itu salah satu alternative solusinya adalah menyalurkan air bersih dari pulau terdekatnya yaitu Nusa Penida. Di Nusa Penida terdapat dua mata air yang cukup besar yaitu mata air Guyangan (78 lt/dt) dan Penida (173 lt/dt). Proyeksi kebutuhan air dengan debit harian maksimum $30 \mathrm{lt} / \mathrm{dt}$. Pada kajian ini, kebutuhan air bersih tersebut akan disuplai dari mata air Penida. Pada umumnya pemasangan pipa menyebrang laut dipasang pada dasar laut (seabed) atau mengapung di permukaan air laut. Namun lautan antara pulau Nusa Penida dan Ceningan merupakan jalur pelayaran kapal, dan lautan tersebut merupakan palung curam dengan kedalaman 200 meter maka kedua metode pemasangan pipa tersebut tidak dapat dilakukan. Oleh sebab itu satu-satunya cara adalah memasang pipa melayang pada kedalaman 20 meter di bawah permukaan air laut. Pipa akan menerima berbagai macam gaya-gaya luar akibat tekanan hidrostatis air laut, hydrodinamik arus dan gelombang. Sesuai hasil kajian, pipa menyeberang lautan dengan bentang 1500 meter terdiri dari tiga pipa HDPE berdiameter $140 \mathrm{~mm}$ yang dipasang parallel. Setiap pipa menerima gaya hidrodinamik pada arah vertikal 64.050 Newton arah keatas dan horizontal $71.550 \mathrm{~N} / \mathrm{m}$. Oleh sebab itu untuk mengamankan pipa dari beban gaya-gaya tersebut maka pipa diikat pada jembatan sling baja stainless berdiameter $110 \mathrm{~mm}$. Disamping itu pada setiap jarak 6 meter pada sling jembatan pipa tersebut dipasangi beton ballast load $350 \mathrm{~kg}$ dengan sling penggantung diameter $6 \mathrm{~mm}$. Metode ini pelaksanaannya rumit dan membutuhkan berbagai peralatan pendukung sehingga dibutuhkan biaya kontruksi yang mahal pula. Namun, hal ini perlu dilakukan untuk menyediakan air bersih di Nusa Ceningan dan Lembongan guna meningkatkan perkembangan pariwisata di daerah tersebut.
\end{abstract}

Kata kunci: Air bersih, pipa melayang, menyebrang lautan, kajian gaya

\begin{abstract}
Clean water is a basic need for human life. Likewise the activities of life on the island of Nusa Ceningan and Lembongan need clean water. Considering that the both islands are favorite tourist destinations and are growing rapidly, in addition to the daily life of the community (7153 people), the availability of clean water is needed for hotels and tourism supporting activities. However, on both islands there are no sources of clean water. Therefore, one alternative solution is to distribute clean water from the nearest island, Nusa Penida. On the Nusa Penida there are two fairly large springs, namely the Guyangan spring (78 It/sec) and Penida (173 It/sec). The projection of water demand until 2043 at daily maximum capacity is $30 \mathrm{lt} / \mathrm{sec}$. In this study, the need for clean water will be supplied from the Penida spring. In general, the installation of crossing pipeline is installed on the seabed or floating on the sea water surface. However, the sea between the Nusa Penida and Ceningan islands is a ship's shipping lane, and the sea is a steep trough with a depth of 200 meters, so the both methods of mounting the pipe cannot be performed. Therefore the only way is drifting the pipeline at a depth of 20 meters below sea level. The pipe will receive various external forces due to the hydrostatic pressure of seawater, hydrodynamic of currents and waves. According to the results of the study, the pipeline crossing the ocean with a span of 1500 meters consists of three HDPE pipes with a diameter of 140 mm which are installed parallel. Each pipe receives hydrodynamic forces that are vertical force of 64,050 Newton in upper direction and horizontal force of 71,550 Newton. Therefore to secure the pipeline from the load of these forces, the pipe is tied to a stainless steel sling bridge with a diameter of $110 \mathrm{~mm}$. Besides that, at every distance of 6 meters the pipe bridge sling is fitted with a ballast concrete load of $350 \mathrm{~kg}$ with a hanging sling of $6 \mathrm{~mm}$. This method is complicated and requires a variety of supporting equipment, so its construction cost is expensive. However, this should be done to provide clean water in the Nusa Ceningan and Lembongan in order to increase the development of tourism in the area.
\end{abstract}

Keywords: Clean water, drifting pipes, crossing the ocean, forces analysis

\section{Pendahuluan}

Perpipaan di bawah laut (subsea pipeline) telah banyak diaplikasikan di dunia untuk menyalurkan minyak dan gas. Berbagai konfigurasi sistem perpipaan dapat dipilih berdasarkan berbagai factor seperti lokasi, kedalaman air laut, kondisi lingkungan, fungsi dan desain umurnya [1].

Terdapat beberapa metode instalasi pipa di bawah air laut, meliputi:
- Metode S-Lay. Metode yang digunakan untuk di daerah perairan dangkal ( $<150$ meter)

- Metode J-Lay. Metode yang digunakan untuk di daerah perairan sedang (150 300 meter)

- Metode Reel-Lay. Metode yang digunakan untuk di daerah perairan dalam ( $>300$ meter)

Metode lain yang digunakan untuk instalasi pipa adalah Shore Pull method, dan Tow method yang biasa dibagi menjadi beberapa jenis yaitu bottom tow, off-bottom tow, mid depth tow, dan surface tow. 
Pembebanan dalam pipa di dalam air laut dapat digolongkan menjadi dua yaitu beban fungsional dan beban lingkungan. Beban beban tersebut harus ditentukan terlebih dalam dalam mendesain sistem perpipaan. Beban fungsional adalah beban yang bekerja pada pipa akibat beban fisik pipa tersebut, meliputi gaya berat pipa dan isinya, gaya tekanan internal dan ekternal pipa, beban ekspansi dan konstaksi termal dari temperature kerja, dan beban pra-tegangan akibat tekanan yang terjadi saat aktivitas pemasangan pipa tersebut. Sedangkan beban lingkungan adalah beban yang bekerja pada pipa akibat pengaruh kondisi lingkungan sekitar pipa, seperti angin, gelombang, arus laut, beban hidrodinamik, dan fenomena lainnya seperti soil liquefaction yang dapat menggeser posisi pipa sehingga dapat mengakibatkan buckling akibat terjadinya bentangan bebas (freespan) serta terjadinya perubahan longitudinal stress pada pipa yang terpasang [2]

Permukaan dasar laut pada umumnya tidak rata, oleh sebab itu celah antara pipa dan dasar laut juga mempengaruhi distribusi gaya hidrodinamik pada pipa by [3]. Distribusi tekanan disekitar pipa mempengaruhi gaya drag dan lift pada pipa [4]. Koefisien-koefisien gaya bukan hanya tergantung pada celah tersebut, namun osilasi aliran akibat gelombang dan arus laut mengakibatkan ketidak stabilan pipa. [5]. Gelombang laut dibangkitkan oleh angin, yang dapat disumsikan bahwa di dalam air laut komponen vertical gerakan gelombang cenderung nol mendekati dasar laut. [6].

Berdasarkan data pelayanan oleh PDAM Klungkung, terdapat dua desa yang belum mendapat pelayanan sampai saat ini yaitu Desa Jungutbatu dan Desa Lembongan yang merupakan wilayah kepulauan yaitu Pulau Nusa Ceningan dan Pulau Nusa Lembongan. Kedua pulau tersebut dipisahkan oleh Selat Toyapakeh dengan pulau utama (Pulau Nusa Penida), dan di kedua pulau tersebut tidak terdapat sumber air bersih untuk memenuhi kebutuhan air baku di pulau tersebut. Oleh sebab itu salah satu solusi alternatifnya adalah menyalurkan air bersih dari sumber yang masih berlebih di Pulau Nusa Penida ke Pulau Ceningan dan Lembongan.

Salah satu contoh pengaliran air dengan metode pemasangan pipa dibawah air laut di Indonesia adalah pipa bawah laut yang menghubungkan antara Pulau Maitara dan Pulau Tidore. Pipa jenis HDPE dipasang di dasar laut dengan metode TT (tarik-tenggelamkan), seperti pada Gambar 1. [7]

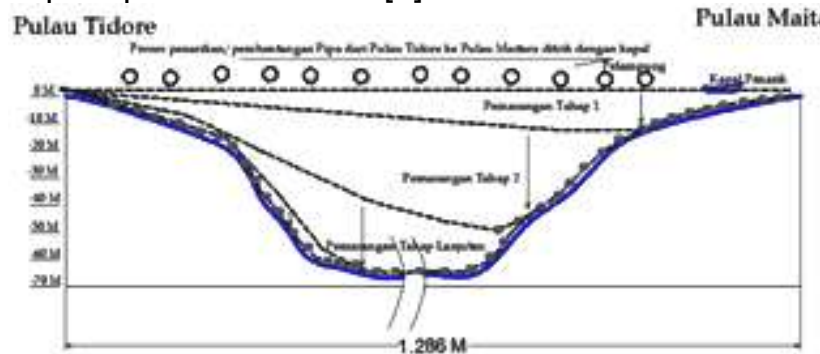

Gambar 1. Pemasangan pipa bawah laut antara Pulau Maitara dan Pulau Tidore

Suatu tantangan besar yang dihadapi untuk menyalurkan air bersih dari pulau Nusa Penida ke pulau Nusa Ceningan dan Lembongan melalui pipa di bawah air laut. Metode pemasangan perpipaan, pemilihan pipa dan keterbatasan pemasangan pipa di bawah air laut. Sehingga mempengaruhi seberapa dalam pipa dapat diinstalasi. Pemasangan perpipaan di bawah air laut dibatasi oleh kapal untuk memasang perpipaan tersebut, juga solusi teknis dan desainnya untuk menjamin kelayakan operasi dan pemeliharaan sistem perpipaan tersebut. Disamping itu, ukuran dan berat pipa, material pipa, arus dan gelombang laut dan kondisi dasar laut, semuanya berkontribusi terhadap tantangan pemasangan pipa.

Sirkulasi arus laut di sekitar perairan Nusa Penida, Bali telah telah diidentifikasi dengan metode numerik. Pola arus di lapisan permukaan dominan dipengaruhi oleh pola pasang surut di daerah tersebut. Kecepatan rata-rata arus laut di perairan Nusa Penida berkisar antara 0.1-0.95 m/s sedangkan kecepatan maksimum di beberapa titik mencapai kisaran angka 2-2.5 m/s [8].

Oleh sebab itu sangat penting untuk dapat mengidentifikasi gaya-gaya yang bekerja pada sistem perpipaan di bawah air laut, khususnya perpipaan crossing laut antara pulau Nusa Penida dan pulau Nusa Ceningan dan Nusa Lembongan dalam upaya untuk menyalurkan air bersih guna mendukung pariwisata di kepulauan tersebut.

\section{Metode Penelitian}

Dalam aplikasi pipa di bawah air, desain dan pemasangan pipa PE terdiri dari langkah-langkah dasar sebagai berikut [9]:

a) Penentuan diameter pipa

b) Pemilihan SDR pipa yang sesuai (ketebalan pipa) termasuk dalam mengantisipasi kondisi pemasangan dan operasinya.

c) Perencanaan berat dan jarak ballast weights untuk menenggelamkan dan menstabilkan posisi pipa.

d) Pemilihan lokasi yang sesuai untuk melansir, menyambung dan menarik pipa.

e) Proses pemasangan dan pengikatan pipa pada sling penahan dan pengarah.

f) Pemasangan dan pengikatan ballast weights.

g) Pengisian pipa dengan air

h) Penenggelaman pipa hingga pada kedalaman yang direncanakan.

i) Penyelesaian pekerjaan dalam penyambungan pipa crossing laut dan pipa di daratan.

\subsection{Proyeksi Jumlah Penduduk dan Kebutuhan Air}

Kebutuhan air bersih untuk berbagai macam kebutuhan masyarakat sehari-hari pada umumnya dapat dibagi atas dua kelompok yaitu kebutuhan domestik dan kebutuhan non domestik. Kebutuhan domestik merupakan kebutuhan air bersih yang digunakan untuk keperluan rumah tangga melalui sambungan kran ke rumah-rumah dan umum, yang jumlah kebutuhannya dapat dilihat dari catatan (data) dari kota atau daerah bersangkutan berdasarkan karakteristik dan perkembangan konsumen pemakai air bersih daerah tersebut.

Berdasarkan Peraturan Menteri Pekerjaan Umum Nomor: 18/Prt/M/2007 tentang Penyelenggaraan Pengembangan Sistem Penyediaan Air Minum, maka proyeksi jumlah penduduk dihitung dengan metode geometrik, dan kebutuhan air domestik dengan tingkat pemakaian air masyarakat adalah $130 \mathrm{lt} / \mathrm{org} /$ hari. 
Demikian pula kebutuhan air non-domestik dihitung berdasarkan fasilitas yang tersedia, dan tingkat kehilangan air direncanakan sebesar $20 \%$ dari kebutuhan konsumsi.

Besar pemakaian air oleh masyarakat pada suatu sistem jaringan distribusi air bersih tidak berlangsung konstan namun terjadi fluktuasi antara satu jam dengan jam lainnya, begitu pula antara satu hari dengan hari lainnya, fluktuasi yang terjadi tergantung pada aktivitas penggunaan air dalam keseharian oleh masyarakat. Fluktuasi pemakaian air bersih dapat dibedakan menjadi tiga [10] :

1). Pemakaian air hari maksimum (Qmax)

Dalam suatu periode tertentu seperti minggu, bulan atau tahun terdapat hari tertentu dimana terjadi pemakaian hari maksimum, yang besarnya sama dengan $115 \%$ dari kebutuhan air rata-rata (Qrata). Kebutuhan air pada hari maksimum ditentukan sebagai bahan pertimbangan dalam menentukan dimensi dari pipa transmisi dan instalasi pengolahan air yang dibutuhkan.

2). Pemakaian air jam puncak (Qpeak)

Dalam sehari, pada jam tertentu terjadi pemakaian air yang maksimum, hal ini terjadi karena pada jam tersebut terjadi pemakaian air yang serentak secara bersamaan, yang besarnya sama dengan 150\% dari kebutuhan air rata-rata (Qrata). Kebutuhan air pada jam puncak ditentukan sebagai bahan pertimbangan dalam menentukan dimensi pipa distribusi dan Volume reservoar.

\section{3). Pemakaian air jam minimum (Qmin)}

Dalam sehari, pada jam tertentu terjadi pemakaian air yang minimum, hal ini terjadi karena pada jam tersebut terjadi pemakaian air yang minim. Debit minimum besarnya sama dengan $30 \%$ dari kebutuhan air rata-rata (Qrata). Biasanya terjadi pada saat dini hari atau aktifitas masyarakat menurun. Kebutuhan air pada jam minimum ditentukan sebagai bahan pertimbangan dalam menentukan dimensi dari reservoar.

\subsection{Tegangan Sistem Perpipaan}

Tegangan pada sistem perpipaan antara lain dapat disebabkan karena tekanan hidrostatis, water hammer, bending (tekukan), temperature. Kecepatan arus pada perairan Toyapakeh cenderung lebih rendah dikarenakan penampang aliran yang membesar.

Adapun parameter yang digunakan dalam perencanaan pipa transmisi air bersih dari pulau Nusa Penida ke pulau Nusa Ceningan adalah:

- Pipa dipasang melayang pada kedalaman 20 meter di bawah permukaan air laut

- Panjang pipa crossing laut 1500 meter

- Kecepatan arus laut pada kedalaman 20 meter adalah $0.5 \mathrm{~m} / \mathrm{dt}$.

- Jarak antar ballast load adalah 6 meter

\section{Hasil dan Pembahasan}

\subsection{Kebutuhan Air Bersih}

Pemanfaatan sumber air bersih yang ada di pulau Nusa Penida untuk memenuhi kebutuhan air di pulau Ceningan dan Lembongan memerlukan kajian neraca air untuk mengetahui sisa debit yang bisa dimanfaatkan. Untuk itu pertama-tama harus dihitung proyeksi jumlah penduduk dan kebutuhan air untuk kecamatan Nusa Penida kabupaten Klungkung adalah seperti pada Tabel 1, kemudian didapatkan sisa debit air, seperti pada Tabel 2, yang bisa dimanfaatkan untuk disalurkan ke pulau Ceningan dan Lembongan. Jadi hingga tahun proyeksi 2043 masih tersedia debit air 177 lt/dt (73\%) yang bisa dimanfaatkan.

Tabel 1. Proyeksi kebutuhan air bersih total di pulau Nusa Penida

\begin{tabular}{|c|c|c|c|c|c|c|c|}
\hline \multirow[t]{2}{*}{ No } & \multirow[t]{2}{*}{ Uraian } & \multirow[t]{2}{*}{ Satuan } & \multicolumn{5}{|c|}{ Tahun } \\
\hline & & & 2023 & 2028 & 2033 & 2038 & 2043 \\
\hline \multicolumn{8}{|c|}{\begin{tabular}{|l|l} 
A & Parameter yang ditetapkan \\
\end{tabular}} \\
\hline & $\begin{array}{l}\text { Rumah tangga } \\
\text { Kran umum }\end{array}$ & $\begin{array}{l}\text { jiwa/samb. } \\
\text { jiwa/samb. }\end{array}$ & $\begin{array}{r}5 \\
100\end{array}$ & $\begin{array}{r}5 \\
100\end{array}$ & $\begin{array}{r}5 \\
100\end{array}$ & $\begin{array}{r}5 \\
100\end{array}$ & $\begin{array}{r}5 \\
100\end{array}$ \\
\hline & $\begin{array}{l}2 \text { Faktor pemakaian air } \\
\text { - Harian maksimum }\end{array}$ & & 1.15 & 1.15 & 1.15 & 1.15 & 1.15 \\
\hline & -Jam puncak & & 1.56 & 1.56 & 1.56 & 1.56 & 1.56 \\
\hline \multirow{2}{*}{\multicolumn{7}{|c|}{ B Perhitungan kebutuhan air }} & $20 \%$ \\
\hline & & & & & & & 45055 \\
\hline 2 & Penduduk yang dilayani & $\%$ & $60.0 \%$ & $70.0 \%$ & $80.0 \%$ & $90.0 \%$ & $100.0 \%$ \\
\hline & Jumlah penduduk yang dillayani & jiwa. & 24,003 & 28,801 & 33,889 & 39,297 & 45,055 \\
\hline \multicolumn{8}{|c|}{$\begin{array}{ll}4 & \begin{array}{l}\text { Kebutuhan air domestik } \\
\text { a. Sambungan rumah tangga }\end{array}\end{array}$} \\
\hline & pemakaian air & Vorang/hari & 80 & 80 & 80 & 80 & 80 \\
\hline & $\begin{array}{l}\text { prosentase pelayananan } \mathrm{SR} \\
\text { jumlah penduduk yang dilayani }\end{array}$ & $\begin{array}{l}\% \\
\text { jiwa }\end{array}$ & $\begin{array}{r}70 \\
16802\end{array}$ & 20161 & $\begin{array}{r}70 \\
23,723\end{array}$ & 27,708 & $\begin{array}{r}70 \\
31,538\end{array}$ \\
\hline & jumlah & unit & 3360 & 4032 & 4,745 & 5,502 & 6,308 \\
\hline & jumlah sambungan tambahan & unit & & 672 & 1,384 & 2,141 & 2,947 \\
\hline & $\begin{array}{l}\text { kebutuhaan air SR } \\
\text { b. Sambungan kran umum }\end{array}$ & $\mathrm{m}^{3} /$ hari & 1344 & 1613 & 1,898 & 2,201 & 2,523 \\
\hline & pemakaian air & Vorang/hari & 30 & 30 & 30 & & \\
\hline & prosentase pelayanan & $\%$ & 30 & 30 & & & \\
\hline & jumlah penduduk yang dilayani & jiwa & 7201 & 8640 & 10,167 & 11,789 & 13,516 \\
\hline & jumlah sambungan & unit & 72 & 86 & 102 & 118 & 135 \\
\hline & kebutuhan air kran umum & $\mathrm{m}^{3} /$ hari & 216 & 259 & 305 & 354 & 405 \\
\hline & Total kebutuhan domestik & $\mathrm{m}^{3} /$ hari & 1,560 & 1,872 & 2,203 & 2,554 & 2,929 \\
\hline & & & 18.06 & 21.67 & 25.50 & 29.56 & 33.90 \\
\hline \multicolumn{8}{|c|}{\begin{tabular}{l|l}
5 & Kebutuh. \\
\end{tabular}} \\
\hline & a. Pendidik & $\mathrm{m}^{3} /$ hari & 89.60 & 126.83 & 151.09 & 179.99 & 214.42 \\
\hline & b. Industri & $\mathrm{m}^{3} /$ hari & 49.70 & 59.21 & 70.53 & 84.02 & 100.09 \\
\hline & c. Perkantoran & $\mathrm{m}^{3} /$ hari & 172.50 & 172.50 & 172.50 & 172.50 & 172.50 \\
\hline & d. Peribadatan & $\mathrm{m}^{3} /$ hari & 76.38 & 80.88 & 80.38 & 84.88 & 89.38 \\
\hline & e. Pariwisata & $\mathrm{m}^{3} /$ hari & 199.32 & 237.44 & 282.86 & 336.96 & 401.41 \\
\hline & f. Kesehatan & $\mathrm{m}^{3} /$ hari & 28.00 & 28.00 & 28.00 & 28.00 & 28.00 \\
\hline & g. Sarana Ekonomi & $\mathrm{m}^{3} /$ hari & 302.35 & 360.18 & 429.07 & 511.14 & 608.91 \\
\hline & h. Fasilitas umum lainnya & $\mathrm{m}^{3} /$ hari & 60.00 & 60.00 & 60.00 & 60.00 & 60.00 \\
\hline & Total kebutuhan non domestik air & $\mathrm{m}^{3 / 2}$ hari & 978 & 1125 & 1274 & 1457 & 1675 \\
\hline & & I/det & 11.32 & 13.02 & 14.75 & 16.87 & 19.38 \\
\hline 6 & Kebutuhan domestik dan non domestik & $\mathrm{m}^{3 / \text { hari }}$ & 2538 & 2997 & 3477 & 4012 & 4603 \\
\hline 7 & Kehilangan air & $\mathrm{m}^{3} /$ hari & 196 & 225 & 255 & 291 & 335 \\
\hline 8 & Kebutuhan air rata-rata & $\mathrm{m}^{3 / h a r i}$ & 2734 & 3222 & 3732 & 4303 & 4938 \\
\hline & & I/det & 32 & 37 & 43 & 50 & $57>0>0$ \\
\hline & $K_{k}$ & $1 / d$ & 36 & 43 & 50 & & \\
\hline & Kebutuhan jam puncak & I/det & & & & & \\
\hline
\end{tabular}

Tabel 2. Neraca Air di Pulau Nusa Penida dengan dua Sumber Air Baku (MA. Penida dan MA. Guyangan)

\begin{tabular}{|c|l|c|c|c|c|c|}
\hline \multirow{2}{*}{ No } & \multicolumn{1}{|c|}{ Uraian } & \multicolumn{5}{|c|}{ Debit (I/dt) } \\
\cline { 3 - 8 } & & 2023 & 2028 & 2033 & 2038 & 2043 \\
\hline 1 & Kapasitas Sumber & & & & & \\
\hline & b. Mata air Penida & 173 & 173 & 173 & 173 & 173 \\
\hline & C. Mata Guyangan & 70 & 70 & 70 & 70 & 70 \\
\hline 2 & Total Kapasitas Sumber & 243 & 243 & 243 & 243 & 243 \\
\hline 3 & Proyeksi Kebutuhan Air & 36 & 43 & 50 & 57 & 66 \\
\hline 4 & Sisa Kapasitas Debit (It/det) & 207 & 200 & 193 & 186 & 177 \\
\hline & Sisa Debit dalam \% & $85 \%$ & $82 \%$ & $80 \%$ & $76 \%$ & $73 \%$ \\
\hline
\end{tabular}

Sedangkan khusus untuk kepulau Ceningan dan Lembongan proyeksi jumlah penduduk dan kebutuhan airnya adalah seperti pada Tabel 3. Proyeksi jumlah penduduknya hingga tahun 2043 adalah 10.819 jiwa dengan kebutuhan air bersih domestik $703 \mathrm{~m}^{3} /$ hari $(8,14 \mathrm{lt} / \mathrm{dt})$, dan kebutuhan air non-domestiknya adalah $1.315 \mathrm{~m}^{3} /$ hari $(15,22 \mathrm{lt} / \mathrm{dt})$ sehingga kebutuhan total debitnya adalah $2.018 \mathrm{~m}^{3} /$ hari. Dengan menambahkan kehilangan air (20\%) sebesar $263 \mathrm{~m}^{3} /$ hari, maka kebutuhan airnya menjadi $2.281 \mathrm{~m}^{3} /$ hari, dengan debit rata-rata $26 \mathrm{lt} / \mathrm{dt}$, debit harian maksimum $30 \mathrm{lt} / \mathrm{dt}$, dan debit jam puncak $41 \mathrm{lt} / \mathrm{dt}$. Sehingga neraca airnya menunjukkan sisa debit yang masih tersedia di pulau Nusa Penida sebesar 147 lt/dt, seperti pada Tabel 4. 
Tabel 3. Proyeksi Kebutuhan Air Baku Total di Pulau Nusa Ceningan dan Nusa Lembongan

\begin{tabular}{|c|c|c|c|c|c|c|c|}
\hline \multirow[t]{2}{*}{ No } & \multirow[t]{2}{*}{ Uraian } & \multirow[t]{2}{*}{ Satuan } & \multicolumn{5}{|c|}{ Tahun } \\
\hline & & & 2023 & 2028 & 2033 & 2038 & 2043 \\
\hline $\mathbf{A}_{1}$ & $\begin{array}{l}\text { Parameter yang ditetapkan } \\
\text { Penduduk yang dilayani tiap sambungan } \\
\text { Rumah tangga } \\
\text { Kran umum } \\
\text { Faktor pemakaian air } \\
\text { - Harian maksimum } \\
\text {-Jam puncak } \\
\text { Kehilangan }\end{array}$ & $\begin{array}{l}\text { jiwa/samb. } \\
\text { jiwa/samb. }\end{array}$ & $\begin{array}{l}1.15 \\
1.56 \\
20 \%\end{array}$ & $\begin{array}{r}5 \\
100 \\
1.15 \\
1.56 \\
20 \%\end{array}$ & $\begin{array}{l}1.15 \\
1.56 \\
20 \%\end{array}$ & $\begin{array}{r}5 \\
100 \\
1.15 \\
1.56 \\
20 \%\end{array}$ & $\begin{array}{l}1.15 \\
1.56 \\
20 \%\end{array}$ \\
\hline B & Perhitungan kebutuhan air & & & & & & \\
\hline 1 & Jumlah penduduk & jiwa. & 8,033 & 8,654 & 9,323 & 10,043 & 10,819 \\
\hline 2 & Penduduk y & $\%$ & $60.0 \%$ & & $80.0 \%$ & $90.0 \%$ & $100.0 \%$ \\
\hline 3 & Jumlah penduduk yang dilayani & $\begin{array}{l}\text { jiwa. } \\
\text { jo. }\end{array}$ & 4,820 & 6,058 & 7,458 & 9,039 & 10,819 \\
\hline & \begin{tabular}{|l} 
Kebutuhan air domestik \\
a. Sambungan rumah tangga
\end{tabular} & & & & & & \\
\hline & $\begin{array}{l}\text { pemakaian air } \\
\text { prosentase pelayanan SR }\end{array}$ & $\begin{array}{c}\text { Vorang/hari } \\
\%\end{array}$ & $\begin{array}{l}80 \\
70\end{array}$ & $\begin{array}{l}80 \\
70\end{array}$ & $\begin{array}{l}80 \\
70\end{array}$ & $\begin{array}{l}80 \\
70\end{array}$ & $\begin{array}{l}80 \\
70\end{array}$ \\
\hline & jumlah penduduk yang dilayani & jiwa & 3374 & 4240 & 5221 & 6327 & 7574 \\
\hline & jumlah sambungan & unit & 675 & 848 & 1044 & 1265 & 1515 \\
\hline & jumlah sambu & un & & 173 & 369 & 591 & 840 \\
\hline & $\begin{array}{l}\text { kebutuhaan air SR } \\
\text { b. Sambungan kran umum }\end{array}$ & $\mathrm{m}^{3} /$ hari & 270 & 339 & 418 & 506 & 606 \\
\hline & $\begin{array}{l}\text { pemakaian air } \\
\text { prosentase pelayanan }\end{array}$ & $\begin{array}{l}\text { Vorang/hari } \\
\%\end{array}$ & $\begin{array}{l}30 \\
30\end{array}$ & $\begin{array}{r}30 \\
30\end{array}$ & $\begin{array}{l}30 \\
30\end{array}$ & $\begin{array}{l}30 \\
30\end{array}$ & $\begin{array}{l}30 \\
30\end{array}$ \\
\hline & jumlah penduduk yang dilayani & jiwa & $\begin{array}{r}3446 \\
140\end{array}$ & $\begin{array}{r}3017 \\
1817\end{array}$ & 2237 & $\begin{array}{r}30 \\
2712\end{array}$ & 3246 \\
\hline & jumlah s & & 14 & 18 & 22 & 27 & 32 \\
\hline & kebutuhan air kran umum & $\mathrm{m}^{3} /$ hari & 43 & 55 & 67 & 81 & 97 \\
\hline & Total kebutuhan domestik & $\mathrm{m}^{3} /$ hari & 313 & 394 & 485 & 588 & 703 \\
\hline & & I/det & 3.63 & 4.56 & 5.61 & 6.80 & 8.14 \\
\hline 5 & Kebutuhan air non domestik & & & & & & \\
\hline & a. Pendidikan & $\mathrm{m}^{3} /$ hari & 17 & 20 & 24 & 29 & 34 \\
\hline & b. Industri & $\mathrm{m}^{3} /$ hari & 5 & 6 & 7 & 8 & 10 \\
\hline & c. Perkantoran & $\mathrm{m}^{3} /$ hari & 12 & 12 & 12 & 12 & 12 \\
\hline & d. Peribadatan & $\mathrm{m}^{3} /$ hari & 8 & 8 & 8 & 8 & \\
\hline & e. Pariwisata & /hari & 433 & 516 & 615 & 732 & 872 \\
\hline & f. Kesehatan & $\mathrm{m}^{3} /$ hari & 4 & 4 & 4 & 4 & \\
\hline & g. Sarana Ekonomi & $\mathrm{m}^{3} /$ hari & 186 & 217 & 254 & 298 & 350 \\
\hline & h. Fasilitas umum lainnya & $\mathrm{m}^{3} /$ hari & 15 & 25 & 25 & 25 & 25 \\
\hline & Total kebutuhan non domestik air & $\mathrm{m}^{3} /$ hari & 679 & 807 & 948 & 1115 & 1315 \\
\hline & & & 7.86 & 9.34 & 10.97 & 12.91 & 15.22 \\
\hline 6 & Kebutuhan domestik dan non domestik & $\mathrm{m}^{3 / \text { hari }}$ & 993 & 1201 & 1433 & 1703 & 2018 \\
\hline$\frac{5}{7}$ & Kehilangan air & $\mathrm{m}^{3} /$ hari & 136 & 161 & 190 & 223 & 263 \\
\hline 8 & Kebutuhan air rata-rata & $\mathrm{m}^{3} /$ hari & 1129 & 1363 & 1622 & 1926 & 2281 \\
\hline & & $1 /$ det & 13 & 16 & 19 & 22 & 0 \\
\hline 9 & Kebu & $1 / \mathrm{d} d$ & 15 & 18 & 22 & 26 & $\sqrt{3}+3$ \\
\hline 10 & Kebutuhan ja & $1 / \mathrm{det}$ & 20 & 25 & 29 & 35 & 4 \\
\hline
\end{tabular}

Tabel 4. Neraca Air di Pulau Nusa Ceningan dan Nusa Lembongan dengan Memanfaatkan sisa debit

\begin{tabular}{|c|l|c|c|c|c|c|}
\hline \multirow{2}{*}{ No } & \multicolumn{2}{|c|}{ Uraian } & \multicolumn{5}{|c|}{ Debit (I/dt) } \\
\cline { 3 - 7 } & & 2023 & 2028 & 2033 & 2038 & 2043 \\
\hline 1 & Sisa Debit yg bisa dimanfaatkan & 207 & 200 & 193 & 186 & 177 \\
\hline 2 & Proyeksi Kebutuhan Air & 15 & 18 & 22 & 26 & 30 \\
\hline 3 & Sisa Kapasitas Debit (Itddet) & 192 & 182 & 172 & 160 & 147 \\
\hline & Sisa Debit dalam \% & $93 \%$ & $91 \%$ & $89 \%$ & $86 \%$ & $83 \%$ \\
\hline
\end{tabular}

\subsection{Pemilihan Pipa}

Sejak pertama kali diperkenalkan di tahun 1960an, pipa high density Polyethilene (HDPE) terus meningkat pengaplikasiannya di laut (marine application) terutama karena ketahanannya terhadap galvanic corrosion. Keunggulan lainnya adalah densitas pipa PE sekitar 94\% dari densitas air laut sehingga mengambang [11]. Berdasarkan debit aliran dan tekanan statis dalam pipa serta kondisi liingkunga tempat pemasangan pipa, maka direncanakan/dipilih pipa HDPE sesuai standar SNI 4829.2:2012 untuk pipa untuk pipa PE100. Pertimbangan lainnya adalah flesibilitas dan ringan sehingga mudah dalam pengangkutan dan pemasangannya. Fleksibilitaas tersebut memingkinkan pipa HDPE ditenggelamkan secara perlahan dan dapat menyesuaikan dengan topografi permukaan dasar laut, sehingga dapat menyederhanakan prosedur penenggelaman pipa.

Direncanakan untuk mengalirkan air $30 \mathrm{lt} / \mathrm{dt}$ digunakan tiga lajur pipa sesuai dengan jumlah pompa intakenya, maka dipilih pipa HDPE berdiameter nominal 140 mm PE100, PN 16 bar, masing-masing untuk mengalirkan air dengan debit $10 \mathrm{lt} / \mathrm{dt}$.

\subsection{Kajian gaya-gaya pipa melayang di dalam air laut}

Adapun rencana sistem perpipaan air bersih dari mata air Penida ke pulau Ceningan dan Lembongan adalah seperti pada Gambar 2, sedangkan bagian sistem perpipaan yang melewati air laut adalah seperti pada Gambar 3. Jalur pipa dari bak pelepas tekan (BPT) di Toyapakeh hingga reservoir (R2) di SWRO Ceningan direncanakan berada dibawah laut, yaitu melewati selat Toyapakeh, dengan panjang total 5000 m, membentang dari pantai Toyapakeh - Selat Toyapakeh - SWRO Ceningan. Peletakan pipa tidak di dasar laut (seabed) pada kedalaman 200 m, karena pertimbangan kesulitan dalam teknis pelaksanaan pemasangan (dan pemeliharaan nantinya) pipa. Peletakan pipa direncanakan di kedalaman $20 \mathrm{~m}$ di bawah permukaan air laut (tanpa menyentuh dasar/ melayang), dengan panjang $1500 \mathrm{~m}$. Untuk menstabilkan pipa dibawah laut, maka dipasang kombinasi beban ballast dan kawat sling.
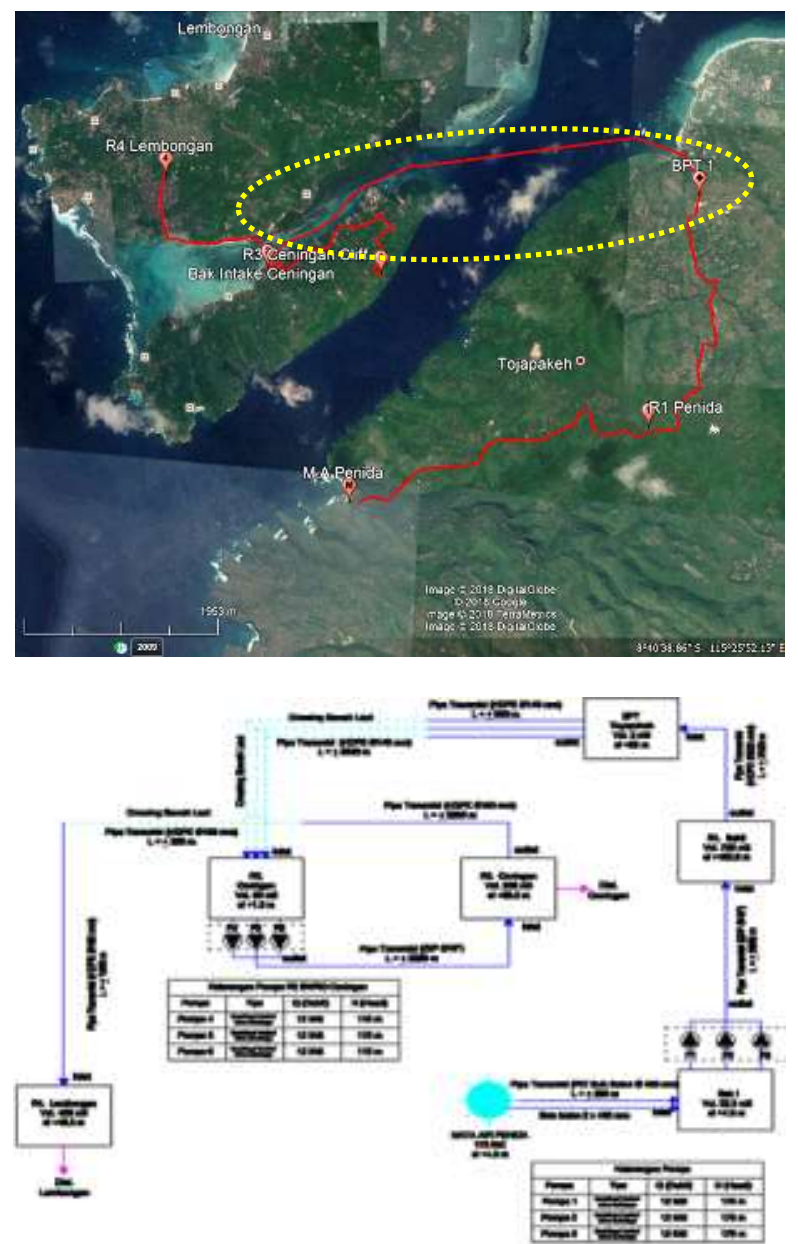

Gambar 2. Sistem perpipaan suplai air bersih dari mata air Penida ke pulau Ceningan dan Lembongan

Instalasi pipa di dalam air laut mengalami gayagaya hydrodinamik akibat gelombang dan arus laut. Secara umum, variasi gaya-gaya tersebut sangat kompleks, oleh sebab itu analisis sederhana dapat digunakan untuk menggambarkan variasi gaya tersebut dengan cara pendekatan [11]. Jika pipa tersebut dipasang melayang di bawah permukaan air laut (immersible / free-span) maka gaya-gaya hidrodinamiknya dapat digambarkan seperti pada Gambar 4. 

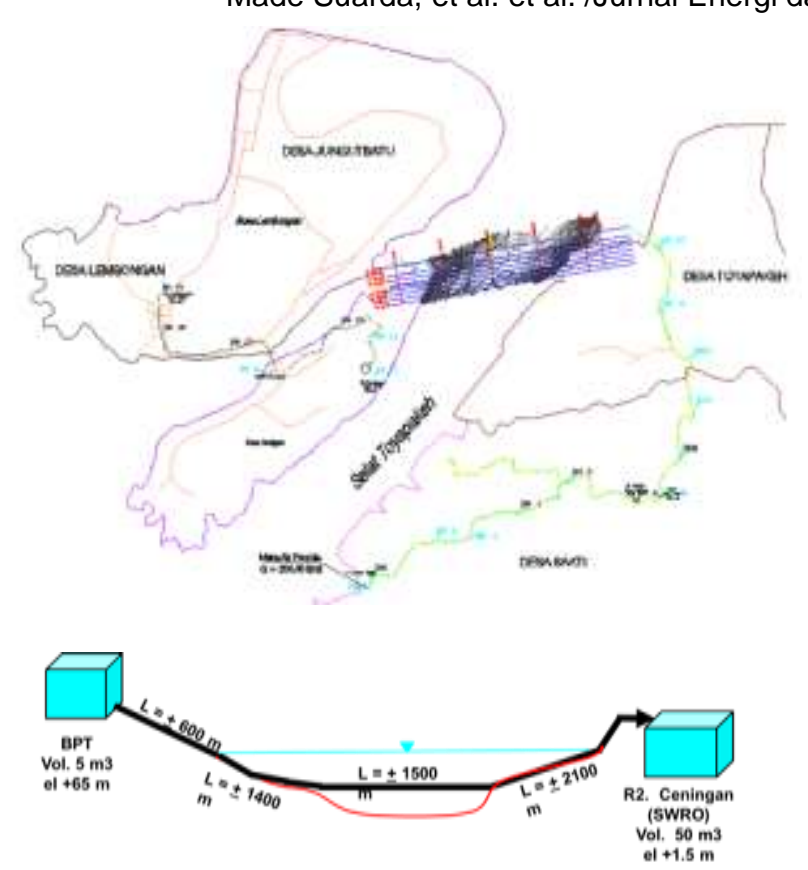

Gambar 3. Sistem perpipaan crossing laut antara pulau Nusa Penida dan pulau Ceningan
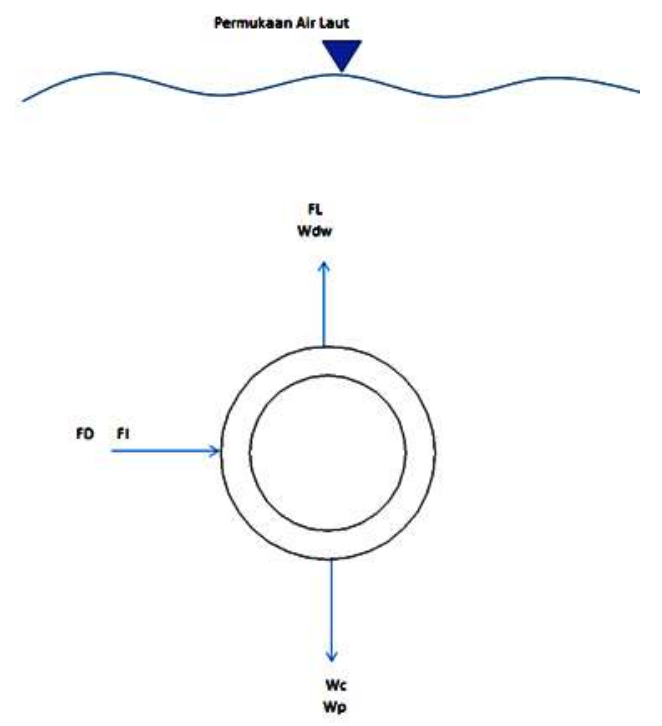

didapat diameter dalam pipa $104,4 \mathrm{~mm}$ sehingga kecepatan alirannya adalah 1,17 $\mathrm{m} / \mathrm{dt}$. Maka berdasarkan SNI 4829.2:2012, dipilih pipa HDPE dengan spesifikasi PE-100, PN 16 bar, SDR 11, diameter nominal (DN) $140 \mathrm{~mm}$, dengan tebal dinding pipa $14,1 \mathrm{~mm}$.

Tekanan hidrostatis maksimum air di dalam pipa, pada bagian pipa terendah di dalam air laut, adalah:

$\mathrm{Po}=\rho . g . h=(1000)(9.81)(65)=637.000$ Pascal Jika terjadi penutupan katup (stop-valve) maka akan terjadi peningkatatan tekanan $15 \%$ menjadi 733.000 Pascal.

Sedangkan tekanan hidrostatik eksternal terhadap pipa pada kedalaman 20 meter dengan massa jenis air laut $1025 \mathrm{~kg} / \mathrm{m}^{3}$ adalah 200.900 Pascal. Jadi tekanan hidrostatis internal lebih besar dari pada eksternal, sehingga diharapkan pipa tidak mengalami perubahan bentuk, dimana tegangan desain nominal pipa adalah $8 \mathrm{MPa}$.

Sesuai dengan spesifikasi pipa HDPE yang dipilih, berat jenis pipa $970 \mathrm{~kg} / \mathrm{m}^{3}$, maka berat pipa adalah $5,4 \mathrm{~kg} / \mathrm{m}$. Sedangkan berat isi (air bersih 1000 $\mathrm{kg} / \mathrm{m}^{3}$ ) pipa adalah $88 \mathrm{~kg} / \mathrm{m}$.

Air laut yang dipindahkan oleh pipa di dalam air laut adalah sama dengan volume pipa, mengakibatkan berat air yang dipindahkan merupakan gaya buoyancy yaitu sebesar $112,6 \mathrm{~kg} / \mathrm{m}$.

Gelombang dan arus air laut mengakibatkan gaya-gaya hidrodinamis seperti gaya seret, gaya angkat dan gaya inersia. Pada diameter luar pipa 140 $\mathrm{mm}$ dalam air laut dengan viskositas $0,000013 \mathrm{~m}^{2} / \mathrm{dt}$ pada kecepatan arus air laut $0,5 \mathrm{~m} / \mathrm{dt}, \mathrm{u}_{\mathrm{t}}=0,76 \mathrm{~m} / \mathrm{dt}$ dan $u_{t}=0,76 \mathrm{~m} / \mathrm{dt}$, maka dengan koefisien drag $\left(C_{D}\right)$ bentuk silindris 1,10 mengakibatkan gaya seret pada pipa menjadi:

$$
F_{D}=C_{D} \cdot(1 / 2) \cdot \rho_{s w} \cdot u_{t}^{2} \cdot D_{0}=46 \mathrm{~N} / \mathrm{m}
$$

dan gaya angkatnya adalah:

$$
F_{L}=C_{L} \cdot(1 / 2) \cdot \rho_{s w} \cdot v_{t}^{2} \cdot D_{0}=37 \mathrm{~N} / \mathrm{m}
$$

Pada kedalaman 20 meter, percepatan gelombang laut adalah $0,234 \mathrm{~m} / \mathrm{dt}^{2}$, maka gaya inersia yang bekerja pada pipa adalah:

$$
F_{I}=C_{I} \cdot \rho_{s w} \cdot a_{w}^{2} \cdot A_{o}=1,7 \mathrm{~N} / \mathrm{m}
$$

Maka kesetimbangan gaya-gaya yang bekerja pada pipa pada arah vertikal adalah:

$$
\begin{aligned}
\Sigma F_{V} & =W_{p}+W_{C}-F_{L}-W_{D W} \\
& =5,4+88-37-112,6 \\
& =-42,7 \mathrm{~N} / \mathrm{m}=-4,4 \mathrm{~kg} / \mathrm{m} \text { (pipa mengapung) } \\
& \begin{aligned}
\Sigma F_{H} & =F_{D}+F_{1} \\
& =46+1,7 \\
& =47,7 \mathrm{~N} / \mathrm{m}=4,8 \mathrm{~kg} / \mathrm{m}
\end{aligned}
\end{aligned}
$$

Kesetimbangan gaya-gaya arah vertical dan horisontalnya adalah:

$$
\begin{aligned}
& \Sigma F_{V}=W_{p}+W_{C}-F_{L}-W_{D W} \\
& \Sigma F_{H}=F_{D}+F_{I}
\end{aligned}
$$

dimana $\mathrm{Wp}$ adalah berat pipa, Wc berat isi pipa, $\mathrm{F}_{\mathrm{L}}$ gaya angkat (lift) pipa, $W_{D W}$ gaya buoyancy, $F_{D}$ gaya seret (drag), dan $F_{1}$ adalah gaya inersia.

Jika direncanakan elevasi hulu pipa yaitu pada bak BPT berada pada elevasi +65 m.dpl dan ujung hilir pipa di bak reservoir R2 di SWRO pada elevasi 1,5 m.dpl dengan panjang pipa keseluruhan adalah 5.600 m. Sedangkan pipa crossing laut dari pulau Nusa Penida ke pulau Ceningan adalah 1.500 meter, maka dengan koefisien gesekan pipa HDPE 0,017 (brosur), maka berdasarkan persamaan:

$$
\Delta \mathrm{Z}=\mathrm{H}_{\mathrm{L}}=\mathrm{K} \cdot \mathrm{Q}^{2}
$$

Sedangkan pada arah horizontal adalah:

Sehingga besar gaya resultannya adalah $63,75 \mathrm{~N} / \mathrm{m}$ atau $6,5 \mathrm{~kg} / \mathrm{m}$ dengan sudut 56,5 derajat (mengapung). Jadi pipa tersebut cenderung bergerak ke arah atas dan kesamping.

Untuk menjaga stabilitas pipa akibat gaya-gaya tersebut maka dipasang ballast load dengan cara mengikat pipa tersebut dengan kawat sling baja stailess ke ballast load yang terletak di dasar laut, pada setiap jarak 6 meter pipa. 


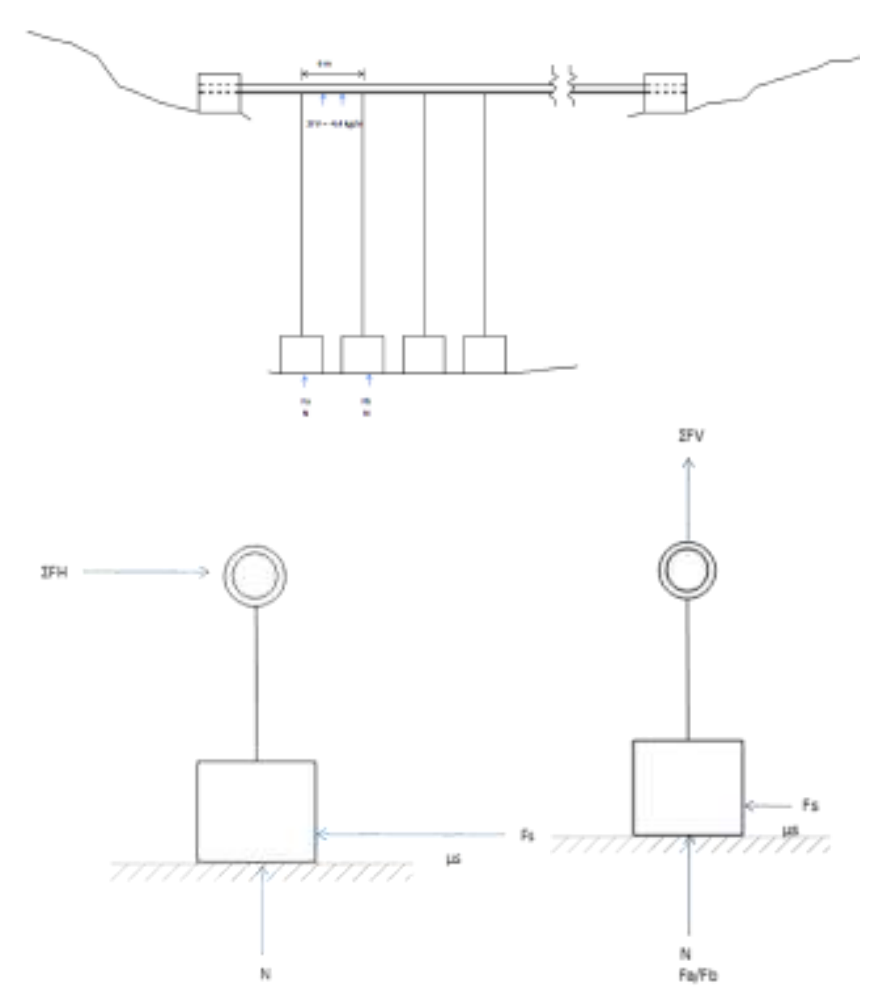

Gambar 5. Ballast load penyeimbang pipa

Pada arah horizontal, momen maksimum yang bekerja pada jarak setiap beban penyeimbang adalah: $M_{H}=\left(\Sigma F_{H} \cdot L^{2}\right) / 8=(4,8 \times 36) / 8=21,7 \mathrm{~kg} \cdot \mathrm{m}$

dan momen horizontal totalnya untuk pipa sepanjang 1.500 meter menjadi:

$$
\mathrm{M}_{\mathrm{Htot}}=1.358 .154 \mathrm{~kg} \cdot \mathrm{m}
$$

sehingga gaya Tarik pada sling utama adalah:

$F_{t . H}=\left(\Sigma F_{H} \cdot L^{2}\right) / 8 d=135.815 \mathrm{~kg} \cdot \mathrm{m}$

Gaya horizontal di beban ballast pada dua ballast load yang berdampingan adalah:

$\mathrm{Fa}=\mathrm{Fb}=(1 / 2)$ (total beban terdistribusi $\mathrm{L}=6 \mathrm{~m})$ $=(1 / 2)(57.9)=29.0 \mathrm{~kg}$

Gaya geser pada arah horizontal:

$\mathrm{Fs} \geq\left(\mathrm{Fa}+\mathrm{F}_{\text {Dballast }}\right)$

$F s \geq 29+22 \geq 51,1 \mathrm{~kg}$

maka gaya normalnya adalah:

$$
\mathrm{N}=\mathrm{Fs} / \mu_{\mathrm{s}}=51,1 / 0,7=73 \mathrm{~kg} \text { (arah keatas) }
$$

Sedangkan pada arah vertical:

$$
M_{V}=\left(\Sigma F_{V} \cdot L^{2}\right) / 8=(-4,4 \times 36) / 8=-19,6 \mathrm{~kg} \cdot \mathrm{m}
$$

dan momen vertica totalnya untuk pipa sepanjang 1.500 meter menjadi:

$$
\mathrm{M}_{\mathrm{H} \text { tot }}=-1.226 .049 \mathrm{~kg} \cdot \mathrm{m}
$$

Gaya vertical di beban ballast pada dua ballast load yang berdampingan adalah:

$\mathrm{Fa}=\mathrm{Fb}=(1 / 2)($ total beban terdistribusi $\mathrm{L}=6 \mathrm{~m})$

$$
=(1 / 2)(-52)=-26 \mathrm{~kg}
$$

Gaya geser pada arah vertica:

$$
\begin{aligned}
& W_{\text {ballast }} \geq(\mathrm{Fa}+\mathrm{N}) \times \mathrm{Sf} \\
& \mathrm{W}_{\text {ballast }} \geq(-26-73) \times 2 \geq-188 \mathrm{~kg}
\end{aligned}
$$

Karena ballast load yang terbuat dari beton tersebut tercelup di dalam air laut maka berat yang dibutuhkan menjadi:

$$
\begin{aligned}
W_{\text {ballast }} & =(188 \times 2400) /(2400-1025) \\
& =328 \mathrm{~kg} \cong 350 \mathrm{~kg}
\end{aligned}
$$

Berdasarkan standar API, angka keamanan minimum tali sling angkat beban adalah 5, maka harus dipilih sling yang mempunyai breaking strength minimal $1.640 \mathrm{~kg}$. Untuk itu dibutuhkan sling tipe Stainless Steel Wire Rope SUS $3167 \times 19$ diameter 6 $\mathrm{mm}$. Sedangkan untuk sling utama jalur pipa dengan bentang $1.500 \mathrm{~m}$ dan desain lendutan maksimum 10 meter, besar gaya tariknya adalah:

$$
\begin{aligned}
\mathrm{F}_{\mathrm{TS}} & =\left(\sum \mathrm{F}_{\mathrm{H}} \times \mathrm{L}^{2}\right) /(8 . \mathrm{e}) \\
& =\left(4,8 \times 1500^{2}\right) /(8 \times 10) \\
& =135.000 \mathrm{~kg}
\end{aligned}
$$

dan jika angka keamanannya direncanakan 5 , maka:

$$
\mathrm{F}_{\mathrm{TS}}=135.000 \times 5=675.000 \mathrm{~kg}
$$

maka dibutuhkan tipe Stainless Steel Wire Rope SUS $3167 \times 19$ diameter $110 \mathrm{~mm}$.

\section{Simpulan}

Untuk memenuhi kebutuhan air bersih di pulau Ceningan dan Lembongan hingga tahun proyeksi 2043 dibutuhkan debit air harian maksimum 30 lt/dt. Direncanakan menggunakan tiga lajur pipa HDPE berdiameter $140 \mathrm{~mm}$ yang menyeberangi lautan dari pulau Nusa Penida ke pulau Ceningan dengan panjang crossing 1500 meter yang dipasang melayang pada kedalaman 20 meter dibawah permukaan air laut. Pipa tersebut menerima gaya hidrodinamik pada arah horizontal 47,7 N/m dengan total gaya 71.550 Newton, dan pada arah vertikal sebesar $42,7 \mathrm{~N} / \mathrm{m}$ dengan total gaya 64.050 Newton arah keatas. Untuk menstabilkan pipa tersebut pada posisinya dibutuhkan ballast load yang terbuat dari beton dengan massa $350 \mathrm{~kg}$ pada setiap 6 meter.

\section{Ucapan Terima Kasih}

Ucapan terima kasih disampaikan kepada Fakultas Teknik Universitas Udayana yang telah mendukung dalam keikutsertaan penulis dalam seminar KNEP 2019 ini.

\section{Daftar Pustaka}

[1] Langhelle M., Pipelines for Development at Deep Water Fields, Master Thesis Marine and Subsea Technology, Universitetet I Stavenger, 2011.

[2] Firucha A.M., Wahyudi, dan Sambodho K., Penilaian Risiko terhadap Pipa Bawah Laut East Java Gas Pipeline (EJGP) Pertagas Akibat Soil Liquefaction karena Gempa Bumi, JURNAL TEKNIK ITS Vol. 1, No. 1, (Sept. 2012).

[3] Yang B., Jeng D.-S, Gao F.P. and Wu Y.X, Forces Acting on the Seabed around A Pipeline in Unidirectional Ocean Currents, The Open Civil Engineering Journal, 2008, Vol. 2, pp. 148-155.

[4] Khalil M.F., Kassab S.Z., Adam I.G., and Samaha M.A., Prediction of Lift and Drag Coefficients on Stationary Capsule in Pipeline, Thirteenth International Water Technology Conference, IWTC 13 2009, Hurghada, Egypt, pp. 435-460.

[5] Leggoe J., and Cheng L., Hydrodynamic Forces on Subsea Pipes due to Orbital Wave Effects, CEED Seminar Proceedings 2011, pp. 1-6.

[6] Abeele F.V.D., and Voorde J.V., Stability of Offshore Pipelines in Close Proximity to the 
Seabed, 6th Pipeline Technology Conference 2011, pp. 1-12.

[7] Hardi W., dan Suyono T., Teknik Pemasangan Pipa Air Minum Bawah Laut dengan Metode TT dari Pulau Tidore ke Pulau Maitara, Seminar Nasional Maritim, Sains, dan Teknologi Terapan 2016 Vol. 01, Politeknik Perkapalan Negeri Surabaya, 21 November 2016, pp. 47-51.

[8] Nugraha R.B.A., Surbakti H., Risandi J. dan Mbay L.O.N., Simulasi Pola Arus Laut Dua Dimensi di Perairan Sekitar Nusa Penida, Bali, https://www.researchgate.net/publication/3038103 42, April 2014, pp. 37-45

[9] Plastics Pipe Institute, Handbook of Polyethylene Pipe, 2009.

[10] Departemen Pekerjaan Umum, Peraturan Menteri Pekerjaan Umum Nomor: 18/Prt/M/2007 tentang Penyelenggaraan Pengembangan Sistem Penyediaan Air Minum.

[11] Braestrup M.W., at.al, Design and Installation of Marine Pipelines, Blackwell Science Ltd, UK, 2005.

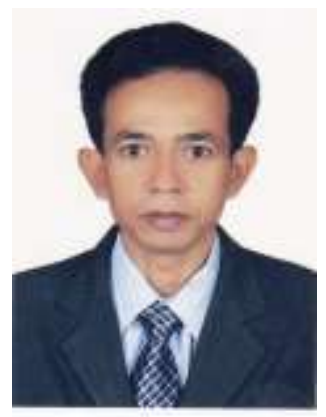

Made Suarda menyelesaikan pendidikan S1 Teknik Permesinan Kapal di ITS Surabaya pada tahun 1989. Pendidikan S2 (Master of Advanced Manufacturing Technology) diselesaikan di University of South Australia pada tahun 2004. Saat ini ia bekerja sebagai dosen di Program Studi Teknik Mesin Uinversitas Udayana. Bidang penelitian utama yang digeluti adalah mesin-mesin konversi energi terutama pompa dan sistem perpipaan. 